\title{
Balkanologie
}

Balkanologie Revue d'études pluridisciplinaires

Vol. V, no 1-2 | 2001

Volume V Numéro 1-2

\section{Fear of becoming minority as a motivator of conflict in the former Yugoslavia}

Dejan Jović

\section{OpenEdition}

1 Journals

\section{Édition électronique}

URL : http://journals.openedition.org/balkanologie/674

DOI : $10.4000 /$ balkanologie. 674

ISSN : 1965-0582

Éditeur

Association française d'études sur les Balkans (Afebalk)

Édition imprimée

Date de publication : 31 décembre 2001

ISSN : 1279-7952

\section{Référence électronique}

Dejan Jović, "Fear of becoming minority as a motivator of conflict in the former Yugoslavia »,

Balkanologie [En ligne], Vol. V, n 1-2 | 2001, mis en ligne le 31 mai 2008, consulté le 17 décembre 2020

URL : http://journals.openedition.org/balkanologie/674; DOI : https://doi.org/10.4000/balkanologie. 674

Ce document a été généré automatiquement le 17 décembre 2020.

(c) Tous droits réservés 


\title{
Fear of becoming minority as a motivator of conflict in the former Yugoslavia
}

\author{
Dejan Jović
}

\begin{abstract}
It is not the Party's role to act as a programmed executor of the "will of the majority"... , [The Party] had to see deeper and further than the broad mass of the people and the "majority.

Edvard Kardelj, 1967

In this sense, one cannot talk here of minority and majority when it comes to the nations in Kosovo. Serbs and Montenegrins are not a minority in relations to Albanians in Kosovo, just like the Albanians are not a minority in Yugoslavia.

Slobodan Milošević, 1987

When we think about the idea that a majority vote should be introduced in a multiethnic federation, we ask : is this anything else but a denial of the equality of the peoples, a denial of sovereignty and of their right to self-determination as an inalienable human right.

Milan Kučan, 1989
\end{abstract}

1 Much of the conflict in the former Yugoslavia is result of fears among its main ethnic groups (whether "nations" or "nationalities") of becoming minorities in newly independent states. It is often argued that those fears are a result of "ancient ethnic hatred" and of the revival of memories of the horrors of the World War II among the Yugoslav ethnic groups. In this paper a different line of argument is presented. I argue that fears of losing ethnic status from "nations" or "nationality" to that of a "minority" are to be understood within a context of the collapse of the ideological narrative of selfmanagement, which was not based on the rule of the majority, but on the notion of consensus and "self-managing harmonisation". Destruction of this self-managing narrative of "no-minority-no-majority" and its replacement with the one of representative democracy (which included the "creation" of both majority and minority) fundamentally disturbed inter-ethnic relations in Yugoslavia. A democratic Yugoslavia would make all ethnic groups (including the Serbs) what they really were - a minority. The fear of becoming a minority (which was created by nationalist members of the counter-elite) was the main reason why a large segment of the population 
supported separation. Rejection of a democratic Yugoslavia was not an "inevitable" outcome of some "ancient ethnic hatred" but a product of combined efforts by conservative members of the political elites (which in the whole post-war period opposed to "unitarism" and "great-statist tendencies") and the nationalist counterelite (mostly in intellectual circles). These two groups were successful in convincing the dominant ethnic groups within their republics that it was in their interest to be a majority in a smaller, rather than minority in larger (and more complex, Yugoslav) state. At the same time, those segments of the former "constitutive nations" and "nationalities" which in new circumstances became minorities (especially Serbs, but also Croats in Bosnia-Herzegovina, as well as Albanians in Serbia) refused to accept the new concept for the same reason: they feared they would become minorities at territories in which they once had been recognised as constitutive. The fears of being existentially endangered if a minority, led all these groups (Slovenes, Croats, Bosnian and Croatian Serbs, Serbian Albanians, Bosnian Croats) towards separatism, and in most cases to authoritarian and military styles of governing in their new political entities. I argue that the fear of becoming a minority was, and remains, a major motivator of conflict in the former Yugoslavia. Subsequently, that conflict is likely to continue for as long as the main Yugoslav ethnic groups fear for their survival.

\section{The Narrative of Yugoslav Socialism : « No-Majority- No-Minorities »}

2 In the socialist Yugoslav federation (1945-1992) all ethnic groups were in a minority: yet the constitutive narrative upon which the social project was based did not recognise the concept of a minority. No ethnic group in the former Yugoslavia was larger than Serbs, but they were only $36,3 \%$ of the Yugoslav population in 1981 . The largest ethnic group, therefore, was still a minority in Yugoslavia with regard to the total population, just as any other ethnic group. Furthermore, just as other main ethnic groups in Yugoslavia (all except Bosnian Muslims, Albanians and Macedonians) their share in population was decreasing ${ }^{1}$. While in 1961 Serbs made $42,1 \%$ of the population, in 1981 they were $36,3 \%$. The share of Croats also fell in this period from $23,2 \%$ to $19,7 \%$. With a growing number of those who declared themselves Yugoslavs in the ethnic sense (increasing from 1,7 \% to 5,4 \% between 1971 and 1981, with an estimation for this number to reach up to $25 \%$ until 2001), Yugoslavia was on its way of becoming even more complex and heterogeneous than ever before.

3 At the same time, the self-managing rhetoric of the Yugoslav communists did not include concepts such as "minorities" and "majorities". In the ethnic sense, the term "national minority" was treated as an outdated category which belonged to the old, pre-socialist political vocabulary. Instead of "minorities" and "majorities", the official classification differentiated between "(constitutive) nations" (narodi) and "nationalities" (narodnosti), leaving some space for "ethnic communities" (etnicke zajednice) in a somewhat gray area of political vocabulary. The six Slavonic constitutive nations were not treated as "minorities" in any part of the Yugoslav territory, not even in those areas where they were in minority (for example, Serbs in Croatia or in Kosovo, Croats in Vojvodina or Bosnia, etc.). Accordingly, unlike Italians, Albanians and Hungarians, they were not offered institutional protection which would normally accompany their "minority" status (autonomous provinces, publishing houses, 
newspapers, separate schools, etc.). Nationalities were also not treated as "minorities". Where they were in majority of the local population (such as Albanians in Kosovo), their position was institutionalised. Where they were in minority (such as Albanians in Macedonia, Italians in Croatia and Slovenia, Hungarians in Vojvodina) - their status did not differ much from a status of "constitutive nations" when in a minority.

It is not only in the political history of Yugoslavia, but also in its constitutive ideology where one can find an explanation for why the notions of "minority" and "majority" were excluded from the political vocabulary. According to the self-managing concept upon which the Yugoslav political system was based, the division of society to its "majority" and "minority", not only in ethnic but also in political and economic sense, was to be overcome as the process of transition to communism advanced. By decentralisation and "socialisation" of the state (podruštvljavanje države), the selfmanaging doctrine constructed a "new form of political and social self-managing community of working people and citizens » in which « self-managing agreements and harmonisation " (samoupravno sporazumijevanje i dogovaranje) should replace permanent divisions between "majorities" and "minorities" 2 . The self-managing process should include everyone or nearly everyone; in theory all "self-managers", (samoupravljače), which were the "subjective force of socialism", with a noticeable exception of the antisocialist forces. The "subjective forces of socialism" were entitled to organise public affairs by gradually replacing the state, through a net of organisations such as "workers councils" in the sphere of production and "Socialist Alliance of Working People" in the sphere of politics. The Yugoslav communists aimed at replacing the state with an "association of free producers". The working class - once the main subject of revolution - was withering away as the process of socialism was advancing towards its realisation. Terms such as "working people and citizens" (radni ljudi i gradjani) were introduced as a replacement for "class". While a "class" could be a minority, the phrase "working people and citizens" was a category which covered neither a minority nor a majority. It was the whole the of population, and it included all except "anti-socialist enemies".

5 Although self-managing socialism recognised the importance of massive participation, and in fact claimed to be the first type of society to include majority of population into process of political decision-making, it was not based on the majority rule principle. As the Programme of the League of Communists of Yugoslavia (LCY) stated in 1958, to be "in the interest" of the majority does not necessarily mean to be supported by the same majority. The majority might be unaware of its own best interests - it might be "blind" about them. This is why - especially in the "first phase of socialism", in the immediate post-revolutionary period - a vanguard is needed to show the proper way and to educate the masses. "Communists, says the Programme of the LCY, must educate the working people to take a greater, more direct and more independent share in the managing of society, and to think and act in a socialist manner, until the very last citizen has learnt to manage the affairs of the community $\|^{3}$. Intellectual superiority ("far-sightedness" dalekovidnost) and not the will of majority was what legitimised the Communist power. Or, as the leading ideologue of Yugoslav socialism, Edvard Kardelj concluded in 1967 :

That democracy is not synonymous with rule by erratic impulse and that it is not the Party's role to act as a programmed executor of the "will of the majority" are fundamentals never forgotten by the Party despite its consistent commitment to democratic goals and the masses. If the party meant to remain the leading force of society, it had to see deeper and further than the broad mass of the people and the 
"majority". The party had to perceive the principal historical meaning of its leading ideological and political role in elaborating the long-term goals of progressive social action and in persevering in its work of transmitting its progressive learning to the broad masses of the people ${ }^{4}$.

It was not only possible, but somehow given by definition that the "vanguard" was not a majority of the population. Communist parties were, for example, clearly a minority in all countries of socialist hemisphere, though they aimed at gradually embracing the majority - and, ideally, the whole population ${ }^{5}$. Socialism was a process of ideological expansion of the vision formulated by the "classics of Marxism" and interpreted by the communist parties to the whole of society. Although coercion remained an important factor in preventing a "counter-revolution", the real change could happen only when the intellectual mission of the Party "once and for all" prevailed over other interpretations of reality and other "directions of development"

The aim of this process was communism, a classless and stateless social formation, based not on the rule of a majority but on harmony, justice and equality among the people. Communism will, once it occurs, not tolerate minorities as a political fact, since their existence would keep the state alive. Being the instrument of the "ruling class", the socialist state indeed was conceptualised as the instrument of the "majority" over "minorities", but with a tendency towards self-destruction.

The anti-state narrative and action that followed it were the key elements of Yugoslav identity under the Communists. The entire project of Yugoslav socialism was based on criticism of Soviet "statism" and of its "hegemonic role" within the world of socialist states. In its essence, therefore, the Yugoslav project was anti-statist. Treating Soviet socialism as "revisionism", the Yugoslav Communists linked elements of the national tradition with strict implementation of the Marxist notion of the "withering away of the state". The other antipode for the Yugoslav anti-statist narrative was the inter-war (bourgeois, centralised, "unitarist") Yugoslavia. Socialist Yugoslavia was to be radically different from it (i.e. revolutionary). It was also meant to be different from both Western and Soviet models, both of which were treated as "statist". Instead, the Yugoslav communists aimed at constructing a new type of social organisation, which would deny the existence of either the "majority" or "minorities" and would reduce the role of the state. The whole history of Yugoslav socialist federalism was based on this vision. Decentralisation of the state was not a result of ethnic pressures from within the country or external pressures from the international community (although both these elements played some role), but was a vision-driven process, initiated primarily by the political elite itself? .

9 In the Yugoslav case, even the word "Party" was in 1952 replaced by the "League" - not only a clear distinction from both the Soviet and West-European cases, but also a clear indication that Yugoslav Communists do not want to represent a part but the whole of society. Kardelj's later opposition to any "party-system", whether "one-" or "multiparty" went as far as saying that in Eastern Europe one party had taken over the role that was performed by many parties in the West, but that was all. Real democracy, however, is only direct, self-managing democracy, to which neither "one-" nor "multiparty" systems can contribute. ${ }^{8}$. What one can conclude from Kardelj's criticism of both types of then existing political systems is that neither the rule of a minority nor of the majority per se is not a guarantor of socialist transformation. Both of them could be (and in reality, as Kardelj believed, were) in certain circumstances potentially 
damaging for the socialist project. The only real guarantor is the LCY and its clear and coherent vision. ${ }^{9}$

The main instrument of this expansion of what once was a party to the whole of society was education ${ }^{10}$. Socialism was a "large classroom" in which the party "taught" the majority (workers) about their own interests, and took care that these interests were realised despite of the will of various majorities and minorities ${ }^{11}$.

The Party had a monopoly on the vision of the future. As Tito said in his concluding speech at the XI LCY Congress 1978 :

Following a critical Marxist analysis of social trends, the League of Communists has arrived at scientific data about the essence of social processes. On this basis it established the directions of the further development of the revolution, ensuring its continuity. At the same time, it armed the working class with these data, making it the conscious subject of socialist development ${ }^{12}$.

In this process, of course, concepts such as "minorities" and the "majority" could hardly find a place. The communist party could not call itself a "minority", although by criterion of simple counting - that is precisely what it was. But the project it led did not aim at the rule of the majority, such as in representative democracies. The majority was not automatically treated as the legitimate ruler, as in representative democracies. In certain situations, i.e. if the achievements of the socialist revolutions were endangered, even if by majority of the population, it was legitimate to intervene against this majority (for example in Czechoslovakia 1968).

To conclude this overview of the narrative of Yugoslav socialism: concepts such as "minority" and "majority" were, for the Yugoslav communists, closely linked to representative democracies, i.e. to "bourgeois political systems", and therefore avoided in the constitution itself. This ideological position was at the core of the institutional structure of the Yugoslav federation, in which republics (and in some cases even provinces) were all treated as equal at the federal level, regardless of the size of their population or territory. Also, within multi-ethnic republics, such as BosniaHerzegovina, Croatia, Macedonia and Serbia, other "constitutive nations" or "nationalities" were not offered any special status or institutional autonomy. Nor were they offered such a status in Kosovo. Although Albanians were the majority in Kosovo, and Serbs in Serbia, the narrative of the regime did not recognise that either of these groups was a majority (and thus should rule as the majority rules in representative democracies, i.e. to form government regardless of the opposition) or a minority (and thus should be protected in the territories where it was a minority). Instead, the rhetoric of «no minorities - no majorities " continued even in the first years after Slobodan Milošević's accession to leading positions in Serbia. Speaking in Kosovo Polje in April 1987, Milošević said :

In this sense, one cannot talk here of minority and majority when it comes to the nations in Kosovo. Serbs and Montenegrins are not a minority in relations to Albanians in Kosovo, just like the Albanians are not a minority in Yugoslavia, but are a nationality [narodnost] that lives together and in equal rights with other nations and nationalities in three of our socialist republics ${ }^{13}$.

14 In the case of differences or a conflict between the Yugoslav nations and republics, it was left to the Party, not to the majority to decide. In a state of emergency, the party presidents at all levels (including the Federation) acted as the real decision-makers. This position was sanctioned by legal provisions which made them ex ufficio heads of the Committees for General People Defence and Social Self-Protection (ONO $i$ DSZ) ${ }^{14}$. 
Constitutional provisions also made party presidents ex-officio members of the presidencies of their respective "socio-political communities" : including the President of the LCY Central Committee who was the ninth member of the Federal State Presidency, without a right of becoming its President or Vice-President. The position of the ninth member could have been of crucial importance in cases such as a stalemate in the decision-making process: it would be up to the party representative to switch to this or that side.

This formula, based on Kardeljist political discourse was seen as crucial in preserving a balance between nations and nationalities in Yugoslavia.

\section{Change of a Discourse : the Emergence of Majorities and Minorities}

The situation, however, changed with the collapse of the socialist discourse. In the Yugoslav case, this collapse happened gradually and to large extent before the eyes of general public. Between 1985 and 1987 the media had opened up for criticism of the regime, but - more importantly - they started broadcasting live political events. In April 1987, Milošević's speech to Serb and Montenegrin protesters in Kosovo Polje presented the crisis of the Party in its full light. In September of the same year, TV cameras were allowed to broadcast the session of the Serbian Central Committee in which Miloševićs line prevailed over that of Ivan Stambolić. By 1988, the direct TV broadcasting of the Central Committee sessions at federal level became a general practice. With this broadcasting, the Party became transparent - more "human" but also clearly perceived as weaker than ever.

The extraordinary place which the LCY had in the political system (as explained above) channelled all political conflicts towards the party itself. Soon it became clear that the Party was in fact an un-elected parliament, much too pluralistic to formulate any vision for the future of Yugoslavia.

18 The crucial step towards the institutional ending of the Kardeljist concept, however, was taken in 1988, when the party initiated (and Yugoslav Assembly accepted) a constitutional amendment by which its direct representation in the Federal Presidency cease to exist. The Central Committee also banned its members from holding state positions, and asked members of all party committees to follow the same rule. The decision demonstrated the Party's intention to separate further from the state structure, and thus to fulfil its promise to be "leading" but not "commanding" force in society. At the same time, however, the change left an open possibility for the Federal Presidency to enter a stalemate with eight, rather than nine members. This indeed soon happened. On the other hand, without a direct representation in the state structures, the Party (led by a Croat Kardeljist Stipe Šuvar) remained a little more than a "chat room" with limited influence over republics and now even over the federal institutions.

The withdrawal of the Party representative from the Federal Presidency was a symbolic sign of a fundamental change. Instead of relying on the decisive role of Party, the "state" now had to rely on a majority of the votes. This first step was soon to be followed by others. In May 1989 Slovenians voted for the first time for their representative in the Federal Presidency, and elected Janez Drnovšek, the first ever member who did not belong to the LCY. When the Party collapsed in January 1990, 
following Slovenian withdrawal at the $14^{\text {th }}$ Extraordinary Congress, there was little left to keep Yugoslavia together.

A couple of months later the republican organisations of the LCY renamed themselves and - more importantly - allowed a new concept (the one of representative democracy) to be introduced.

This new discourse, however, contained in itself notions of both "majority" and "minority". Representative democracy is rule by a majority, which is identified in free and fair elections. Minorities are recognised and protected: but - they could hardly count on being in practice in everything equal with the majority. Regardless of various instruments of minority protection, it is ultimately the majority that takes decisions. Both the doctrine of "self-managing agreement and harmonisation" and the practise of self-management, were now to be replaced by majority voting in which every citizen (not republics or ethnic groups) was treated as equal to every other ${ }^{15}$. Instead of ideological constructions of anti-state "socio-political communities" (as "a new form of social organisation" which was to replace the state), a proper (Yugoslav) state was to be created. Almost inevitably, representative democracy would create a Yugoslav demos instead of six "constitutive nations" and "nationalities". Equally likely, the existence of a Yugoslav "civic nation" would become the main substance of a democratic Yugoslavia's new identity, which would undermine already weak linguistic, religious, cultural and political boundaries between the existing "constitutive nations". Ultimately, a Yugoslav nation would emerge as a product of representative democracy. In normal circumstances, political parties and votes, as well as post-electoral coalitions would cut across ethnic lines ${ }^{16}$. Creation of a Yugoslav democratic parliament, in which citizens would be treated as equal, would destroy equality between large and small nations, but also between "nations" and "nationalities". Albanians would, for example, in this parliament have more representatives than Slovenes, while Montenegrins could not count on one eighth of the vote as they used to have in socialist Yugoslavia. What would, then, be left of Yugoslavia, either as a country of South Slavs (as originally imagined) or as a Kardeljist project of socialist alternative to statism?

In the final phase before the collapse of the Yugoslav state, the main line of political division ran between the supporters of the change (reformists of the constitution) and those who opposed it (defenders of the constitution). When it appeared, the conflict was by no means primarily ethnic. It was a political and ideological gap that divided the leaders : those who wanted to re-establish a state (statists, such as Milošević) from those who preferred the status quo and preservation of Kardeljist constitutive discourse (anti-statists, such as Milan Kučan) ${ }^{17}$.

If one believes, as it is suggested here, that narratives are not only empty words without any resonance among the population, then one can clearly see why so many people (and especially political leaders) remained committed to the old, Kardeljist narrative, rather than accepted a new one which would imply creation of a Yugoslav nation. The opposition to democratic changes by the anti-statists (defenders of the constitution) was perfectly rational as it followed the political interests of their ethnic groups and republics, as understood within the Kardeljist narrative. Being a "constitutive nation" in Yugoslavia, with one eighth of the vote in Federal Presidency, Slovenes (for example) had no reason to support a change which would make them only $8 \%$ of the electorate and deprive them of "veto-mechanisms" reserved for each republic and even in many cases provinces. Even less they had a reason to support a 
one-member-one-vote principle within the LCY, where their share was rapidly decreasing, only to reach five percent of total membership by $1989^{18}$. It made no sense for them to become a minority in a country in which they had been treated as a "constitutive nation". Slovenia's fear of becoming a minority in Yugoslavia was only secondarily linked with the proposed concepts of the new Yugoslavia, although it was clearly encouraged by repressive nature of political actions undertaken or supported by the reformers of the constitution, mostly in Serbia. But, as the Slovene authors clearly said in a series of articles published in the Nova Revija magazine ${ }^{19}$ any Yugoslavia, even the most democratic one (and - one may conclude - especially the most democratic one) would be unacceptable to Slovenes (and in fact many others) if they had to become a minority in it ${ }^{20}$. Even to Serbs, who were the largest nation in Yugoslavia, a democratic Yugoslavia was acceptable only for as long as they were winning in political arena within it. As their refusal to accept a vote of confidence against their representative in the Federal Party Presidency Dušan Čkrebić demonstrated at the $17^{\text {th }}$ CC LCY Session (17 October 1988), the Serbs also feared becoming a minority in Yugoslavia, and therefore - as the previous narrative used to say in a pejorative way - "outvoted" (nadglasani) by an "anti-Serb coalition" ${ }^{21}$. The fear of becoming a minority in Yugoslavia encouraged separatist forces within Serbian nation, which has been for the whole $20^{\text {th }}$ century divided to "pro-Yugoslav" and "proSerbian" groups ${ }^{22}$. Although a majority of Serbs remained ultimately committed to a Yugoslav, not a Serbian orientation, tolerance towards free expression of Serbian separatist nationalism in other republics of the former Yugoslavia further encouraged fears on the side of the majorities in these republics. Serbian, Slovenian (and later certainly Croatian) nationalism indeed fed each other with excuses for their own existence.

The same reason why the Slovenes rejected the democratisation of Yugoslavia, explains why the Serbs rejected the creation of Croatian and Bosnian demos in these two newly independent states after the collapse of Yugoslavia. They feared becoming a minority in territories in which once they had been treated as "constitutive nations". So did the Croats in Bosnia. This was especially the case when the new minorities faced a high birth-rate by new majorities, such as in Kosovo (and to lesser extent - Bosnia) or a strong tendency towards "ethnically mixed marriages" which encouraged the trend of creating "Yugoslavs" (especially in Bosnia and certain parts of Croatia). Fears of being "swallowed" by the new majority - which had already been seen as threat to the achieved ethnic status - created a core of a new narrative. It offered a good starting point for myths, which were then created by leading intellectuals and political actors. Ultimately, it led to crimes against families in both Bosnian and Kosovo conflicts.

\section{Conclusion}

The replacement of one (communist) narrative by another (potentially liberaldemocratic) produced a massive instability and disturbance in inter-ethnic relations in Yugoslavia. Everyone felt somehow endangered by the possibility of losing their status as a "constitutive nation" (or, indeed a "nationality") and becoming once again a simple and powerless "minority". Although many of the new leaders were in favour of citizens' equality within their own republics (they in fact refused to recognise collective rights and identities within them), they stubbornly opposed implementation of the 
same principle at the Yugoslav level. In doing so, they often relied on Kardeljist argument that Yugoslav nations are 'completed' and that an idea of a "Yugoslav nation" represents not only an illusion but a dangerous demand on the sides of either pro-Soviet ("unitarist") or pro-bourgeois ("anti-socialist") forces ${ }^{23}$. In any attempt to constitute a united Yugoslav state (regardless of the level of autonomy offered to its constitutive parts) they saw either a renewal of the "Ranković era" or renewal of "prewar Great-Serbian domination".

Both Kardeljist leaders and ethnic nationalists in the opposition rejected a democratic Yugoslavia which would make every ethnic group what it indeed was : a minority. And in doing so, they were not irrational from the point of view of their own interests. Nor were they irrational from the point of view of the imagined interests of their own ethnic groups and republics / provinces. Why would they agree to be a minority in Yugoslavia, when they can be a majority in their own republics? And since they could not be a majority in Yugoslavia, the choice was indeed reduced to a simple one : minority in a large state or majority in a smaller one. For political elites, already powerful in their republics but increasingly powerless at federal level, the choice was the one between keeping and strengthening power on the one hand and risking to lose it on the other. It made a lot of sense to them to opt for the former, rather than later. By choosing a path of separation, the former constitutive nations became majorities in their own republics. But, significant segments were left outside - and most of them refused to become "minorities". So did Albanians from Kosovo, which perhaps longer than others remained committed (and not without a good reason!) to Kardeljist concept of "no minorities - no majorities".

The refusal of those parts of the former constitutive nations which were now separated by borders from their "national state" to became "minorities" in their new states, as well as of the former "nationalities" (Albanians) to become minorities in a new Yugoslav federation (Serbia-Montenegro) was the main motivator of their actions against those new states. These actions were not primarily due to some mystic remote control from this or that capital of newly created states, although the common understanding and the nationalist character of the new paradigm often brought leaders of the same ethnic group together, regardless of the state borders between them.

The fear of becoming a minority was real and strong in all parts of the former Yugoslavia in a situation of fundamental uncertainty about the future of the country. In Slovenia, those fears increased following the Janša trial in 1988. While in April 1988 (before the trial), $25,4 \%$ of slovenes said they felt « fear and hope at the same time for the future of the country and / or themselves ", and $26,1 \%$ felt « fear and worry only ", these figures rose to $33,9 \%$ and 36,2\% respectively by October 1988 (after the arrest). "Fear» was, therefore, the word which $70,1 \%$ of Slovenes used to describe their feelings on the eve of $1989^{24}$. These fears were not produced by some foreign power, as was often the case in previous years. In April 1988, only 1,5\% of Slovenes believed Yugoslavia was endangered from the West, and 5,9\% saw danger in the East, while an additional $25,8 \%$ said the potential danger came «from them both». If one takes all those who saw any danger from any of the sides together, it was still the case that two thirds $(66,2 \%)$ of Slovenes saw no danger at all from anywhere outside. The source of fear was inside the country, but outside Slovenia - in Belgrade. In Belgrade, however, a majority of the population felt the same sense of fear and uncertainty. In October 1990, only 3,1\% of Serbian population did not feel « worry » or 
«fear " for their personal future and that of their families, while $66,4 \%$ had a «Messianic attitude » described in a sentence : «I am afraid, but I think we can find a way out, if we are united $»^{25}$. The combination of fears and hopes, both in Slovenia and in Serbia (and later in Croatia too) was a perfect pretext for the emergence of authoritarian leaders and "revolutionary" actions they proposed for ending the crisis ${ }^{26}$. Those fears were by no means faked : they were real and strong. They originated in a sense of losing something that had been achieved and guaranteed before. In the Slovenian case, it was a fear of losing a status of the constitutive nation and of "nation state", as recognised in Kardelj's concept of the self-managing Yugoslavia. In the Serbian case, it was fear of losing Yugoslavia, which for the largest number of Serbs was unacceptable ${ }^{27}$.

Those fears were additionally constructed by the main representatives of the "culture of apocalypse" which was developed by the leading anti-regime intellectuals (especially in Serbia and Slovenia) during the $1980 \mathrm{~s}^{28}$. Under a wide umbrella of "breaking with taboos", the leading members of the intellectual elite offered alternative interpretations of recent history (mostly of the WW-II and immediate post-war tragic events) reminding their readership of evil on the side of this or that other nation in Yugoslavia. Those authors mostly shared an ultra-conservative understanding of history and basically believed that «in history there are no accidents and that, in essence, almost nothing is new $»^{29}$. Thus everything tends to repeat itself almost inevitably, and the reminiscences of the past fears were now easily transformed into fears for the future. What happened in 1941-1945 might and will happen again, they argued. The genocide committed in the old times of the Ottoman Empire, or during the Independent State of Croatia (the Ustashe regime in Croatia and Bosnia-Herzegovina) against the Serbs will happen again. As Bogdanović argued analysing the new rhetoric, offered as a replacement for the Kardeljist narrative, its main characteristic was that there was no clear line between myth and reality, between death and life, between past and future ${ }^{30}$.

The rhetoric of apocalypse ${ }^{31}$ and the ultra-conservative interpretation of history developed within the tolerated groups of intellectual counter-elites fell onto fruitful ground of fears and uncertainties. One should not forget that this all happened within a context of a collapsing anti-statism which provided a loose understanding of political obligation and which never developed a proper rule of law. A socialist state, weakened to an almost anarchic situation by its own commitment to anti-statist doctrine and by challenges from the outside of it, was now far too weak to survive. Being unable to protect its citizens from the increasingly felt threat to their own existence, the state in fact opened its doors to a "war-of-all-against-all" situation. It should not be a great surprise then that various nationalist and statists presented themselves as "saviours of the nation" by offering an authoritarian style of governing in almost all post-Yugoslav independent states. The emergence of strong and authoritarian states may be understood only within a context of non-existent "state", which was "withering away" in the end of the 1980s. They were not only a product of authoritarian features of the main leaders in those states, but also of a perception of needs on the part of large segments (newly created majorities) of their population.

The aggression that followed was only a further step, another result of this perception. Fears of becoming minority were easily manipulated before they were transformed into aggression towards others. This aggression was seen as a pure self-defence, as a 
reaction to injustice and a tool of self-protection. We need to look here for the roots of the conflict in the former Yugoslavia, and also for reasons why even today, after a whole decade, many former Yugoslavs still believe that the wars of the 1990s were just and justified.

\section{NOTES}

1. The notion of the "main" ethnic groups refers to Serbs, Croats and Slovenes. Although the Yugoslav constitution treated all nations as equal, both political elite and counter-elites recognised that these three groups had larger influence on Yugoslav politics than others. The former LCY CC President Stipe Šuvar confirmed this in interview I conducted with him in January 1998. For an interesting classification of nations in Yugoslavia from the point of view of a leading Slovenian "dissident" see Urbančič (Ivan), "The Yugoslav "nationalist crisis" and the Slovenes in the perspective of the end of nations ", Nova Revija, (57), 1987.

2. The construction of new reality (as socialism defined its objective) demanded the replacement of old terms linked to the existence of the state with new ones that belonged to the self-managing glossary. Some of these words are almost impossible to translate into any West European language since they were invented to describe institutions uniquely linked to a new form of social organisation. Others had a different connotation than it was the case in the West. For example, state and statism, which were both used with a negative connotation - as something opposed to self-management.

3. The Programme of the League of Yugoslav Communists, Belgrade, 1958, p. 128.

4. Kardelj (Edvard), "Thirty years after the founding congress of the Communist Party of Slovenia » [1967], in The Nations and Socialism, STP : Belgrade, 1980, p. 47.

5. In $1981,13,4 \%$ of the Yugoslav adult population were members of the LCY. Only in Slovenia the share was below $10 \%$ - 9,1. In 1983, however, membership of the LCY began to decrease.

6. The main political conflicts within the Yugoslav political elite were in fact structured over the question of how much repression is desirable and necessary against the "anti-socialist forces". It is today very popular to argue that the main conflicts were always ethnic: but neither the removal of Ranković (1966), nor the action taken against the Croatian Spring (1971), or Serbian "Liberals" in 1972 were primarily motivated by ethnic reasons. All these were primarily intraethnic conflict between members of political elites who had different views on the importance and necessity of repression and "ideo-political work". For this see Tripalo (Miko), Hrvatsko proljeće, Zagreb : Globus, 1991 ; Perović (Latinka), Zatvaranje kruga: ishod političkog rascepa u SKJ 1971-1972, Sarajevo : Svjetlost, 1991 ; and Marković (Dragoslav Draža), Život i politika, Vol. 1-2. Beograd : Rad, 1987-1988. The same goes for conflicts in the post-Tito period : Šuvar-Špiljak in Croatia, or Stambolić-Milošević in Serbia.

7. It is worth noting that Yugoslavia began the last phase of its decentralisation in the mid-1960s, when both West and East faced a crisis of "statism", i.e. at the time of the massive leftist protests in the West, and the Czechoslovak crisis in the East. Yugoslav communists were certainly not forced to initiate such changes - on the contrary, the only relevant protests against the regime (the student protests in Belgrade in 1968) urged them to introduce more "equality" and more state intervention, rather than to decentralise political system. With a bit of cynicism, 
one could conclude that in Yugoslavia leaders wanted the state to wither away, while majority of population (especially workers) wanted less self-management and more state intervention.

8. For Kardelj's views on this see his last book, Kardelj (Edvard), «Ways of Democracy in a Socialist Society » [1977], in Self-Management and the Political System, Belgrade : STP, 1980.

9. Kardelj believed that vision is the key to the unity of a nation. As he said in 1977 : « The unity of the nation is not possible unless based on a clear platform, on a clear outlook for the future development of society » (ibid., p. 263). This is why the unity of Yugoslavia, in fact, ultimately depended on the Party itself.

10. This is why the key ideological issue was "reform of education system". Croatian Communist ideologue Stipe Šuvar was notorious for his attempt to bring the education system in line with Marxist idea of an "association of free producers". He fought "elitism" and introduced courses such as "Marxism », "Theory and Practice of Self-Managing Socialism » and "Production and Technical Education » as compulsory to all high-school curricula.

11. The totalitarian potential of communism as well as its extreme sensitivity to all intellectual activities (even the most benign ones, such as poems, etc.) had its roots in this vision. For the importance of words in socialism, see Havel (Vaclav), "A Word About Words " [1989] and « Power of the Powerless » [1978], in Open Letters, London : Faber and Faber, 1991.

12. Tito (Josip Broz), «The LCY in the Struggle for the Further Development of Socialist, SelfManaging and Non-Aligned Yugoslavia " (Speech at the $11^{\text {th }}$ Congress of the LCY), in $11^{\text {th }}$ Congress of the League of Communists of Yugoslavia, Belgrade : STP, 1978, p. 65.

13. Milo\{evi|, (Slobodan), «Noć i zora u Kosovu Poqu » [Speech in Kosovo Polje, 24-25 April 1987], in Godine raspleta. Beorad : BIGZ, 1989, p. 143.

14. Had 'ić (Miroslav), «The Army's Use of Trauma » [1996], in Popov (Nebojša), ed., The Road to War in Serbia, Budapest : CEU Press, 2000.

15. It is often argued that self-management was no more than an "empty word" with little correspondence with what happened in reality. I do not subscribe to this interpretation. In only four years following the introduction of the Law on Associated Labour (1976-1980), about 94000 basic organisations of associated labour were created in Yugoslavia. Between 1,25 and 1,5 million directives, orders, contracts and other obligatory acts were enacted throughout the system in the first post-Constitutional years (Bilandžić (Dušan), Jugoslavia poslije Tita 1980-1985, Zagreb : Globus, 1986, p. 39). In many cases, such as those described by I. Stambolić (Stambolić (Ivan), Put u Bespuće, Belgrade: B92, 1995, p. 44), a small minority of workers was able to veto majority. Stambolić remembers a case where " seven thousand workers voted for a decision, but the BOAL of the Catering Services voted 31 against and 29 for. Because of these two votes, 7000 workers could not realise their self-managing will». Although it clearly could not break the LCY's monopoly in political sphere, the self-managing system took deep roots in the sphere of production. Self-managing was not jut an empty parole by the regime. It was an illusion to expect it would be "wiped away" from people's memories over night. In fact, some of its key elements came back in workers' protests against privatisation and the corruption of the new authorities in the late 1990s.

16. The last Yugoslav Prime Minister, Ante Marković, begun the process of creating a Yugoslav party, and there were originally encouraging signs of support for this concept. In its last pre-war phase, the main conflict was between Marković's type of Yugoslavism and republican nationalisms. However, the institutional structure of Yugoslavia helped Marković's opponents because its main purpose was to disable any Yugoslav "unitarism" and "hegemonism". Marković, therefore, faced a choice : either to act anti-constitutionally in his attempt to save Yugoslavia or to act constitutionally but with slim chances of saving it. A democratic and united Yugoslavia was becoming as improbable as a Communist-led united Yugoslavia. Not many, however, realised this until very late. For example, as the last US Ambassador to Yugoslavia (1988-1992) Warren Zimmermann writes, the US Government believed that « unity and democracy were the Siamese 
twins of Yugoslavia's fate... the loss of one meant that the other would die " (Zimmermann (Warren), Origins of a Catastrophe, New York: Random House, 1996, p. 6). Marković basically believed the same. However, both Markovićs term in office and American policy in the Balkans ended in failure, partly because they did not understand this.

17. This line of division largely cut across ethnic lines within the Yugoslav political elite - for example, Croatian political leaders of Serb ethnic origins (such as Dušan Dragosavac, Milutin Baltić, etc.) and those from Vojvodina were on the opposite side from the majority of the Serbian leadership. At the same time, as in many previous occasions, the main divisions were within the same ethnic group, not between them: for example, between Slobodan Milošević and Ivan Stambolić in Serbia; and Mika Špiljak and Stipe Šuvar in Croatia, etc.

18. For details of ethnic structure of the LCY see Burg (Burg (Stephan), «New Data on the League of Communists of Yugoslavia ", Slavic Review, 46, 1987, p. 553). The Slovenian LC had 126437 members in 1982. The Slovenes made up 5,2\% of the Party, less than any other constitutive nation in Yugoslavia (including the Montenegrins, four times smaller in total population). This share was further decreasing (and rapidly so) in the mid-1980s.

19. Nova Revija, (57), january 1987.

20. One of the Nova Revija authors, Tine Hribar, opposed both "Yugoslavism" and "Yugoslavianism" (jugoslovanstvo, jugoslavijanstvo), i.e. both Yugoslav nation in ethnic and in political sense respectively. For him, both were equally unacceptable. Both of them would make Slovenians only a minority within a unitary state (Hribar (Tine), "Slovenska dr`avnost ", Nova Revija, (57), 1987). In arguing in favour of independence, many of the Nova Revija authors (such as Jambrek (Peter), «Pravica do samoodločbe slovenskega naroda », Nova Revija 57, 1987, p. 166 ; Urbančič (Ivan), loc. cit., p. 44) used Kardelj's anti-statist concept, which recognised republics as states to support their arguments. Slovenian nationalist opposed Yugoslav "unitarism", not Serbian nationalism. France Bučar and Ivan Urbančič in fact even supported Serbian nationalist claims, but clearly demanded that their Serb counterparts should dissociate themselves from any trace of Yugoslav unitarism (Bučar (France), «Slovenija med Balkanom in Evropo ", Nova Revija, (91), 1989, p. 1497 ; Urbančič (Ivan), loc. cit., p. 39). Finally, it is on this platform that the opposition agreed with the President of the Slovenian LC CC Milan Kučan. On 17 June 1989, Kučan said : "When we think about the idea that a majority vote should be introduced in a multi-ethnic federation, we ask: is this anything else but a denial of the equality of the peoples, a denial of sovereignty and of their right to self-determination as an inalienable human right " (Borba, 19 June 1989). During the first common action by the LCY and Slovenian opposition, at Cankarjev Dom in Ljubljana in February 1989, Kučan said that if policy against Kosovo Albanians continued, " this would be a very clear announcement that the minority nations and nationalities will first be pushed to the margins, and then out of the country, abroad or who knows where " (Bilić (Jovan), Bilbija (Djuro), Slovenija i Srbija od Cankarjevog Doma do Jugoalata i Gazimestana, Belgrade : Tera, 1989, p. 30).

21. The term is coined by Macedonian member of the SFRY Presidency Vasil Tupurkovski - yet another illustration of the conclusion presented here that the line of division within the leadership cut across ethnic lines and did not play the crucial role at that time (1988), as often argued today. For the $17^{\text {th }}$ Session, see Šuvar (Stipe), Nezavrseni mandat 1-2, Zagreb : Globus, 1989. 22. Pavković (Aleksandar), « From Yugoslavism to Serbism : the Serb national idea 1986-1996 », Nations and Nationalism, 4, 1998.

23. Not even the present-day Serbia has abandoned this crucial idea of Kardeljist concept. The FRY does not aim at creating a Yugoslav nation out of Serbs, Montenegrins, Albanians and Hungarians, but remains committed (even after the latest Constitutional change in June 2000) to idea of the equality of two - by size very uneven - nations (Serbs and Montenegrins) and their "sovereign states" (Montenegro and Serbia).

24. Toš (Niko), ed., Slovensko Javno Mnenje 1988-1989, Ljubljana : Delavska Enotnost, 1989, p. 132. 
25. Obradović (Marija), "Vladajuča stranka: ideologija i tehnologija dominacije », in Popov (Nebojša), ur., Srpska strana rata, Belgrade : Republika, 1996, p. 494.

26. About the role of fears in Serbian politics under Milošević, see Djilas (Aleksa), Razgovori za Jugoslaviju, Belgrade: Prometej, 1993. Also, Richard West's description of new atmosphere in Belgrade following the Eighth Session of the CC LC Serbia in September 1987. West, himself a frequent visitor to Belgrade since 1945, writes: «For the first time since I had known Belgrade [so, since 1945 !], I was warned by friends against careless talk in public places, and still more on the telephone. People were keeping their voices down in the café of the Moskva Hotel... » (West (Richard), Tito and the Rise and Fall of Yugoslavia, London: Sinclair-Stevenson, 1994, p. 345). For fears among the political elite, see Bogdanović's analysis of the rhetoric of the Eighth Session. Bogdanović concluded that Milošević's fraction demonstrated « an almost unbelievable fear, real panic of polysemia, of the pluralist meaning of words and speeches, even in describing obviously pluralist events » (Bogdanović (Bogdan), Mrtvou 'ice: Mentalne zamke staljinizma, Zagreb : August Cesarec, 1988, p. 20). For the sense of fear among members of the Yugoslav political elite, see memoirs by B. Jović (Jović (Borisav), Poslednji dani SFRJ, Belgrade : Politika, 1995) - entries on Petar Gračanin and Veljko Kadijević.

27. This is why in 1990 they voted against Vuk Drašković's Serbian Resistance Movement, in favour of a more pro-Yugoslav Milošević's Socialist Party of Serbia. As an illustration of how unpopular were even symbols of Serbian nationalism, see Thompson (Mark), Proizvodnja rata: mediji u Srbiji, Hrvatskoj i Bosni i Hercegovini, Belgrade : Medija centar / Radio B-92, 1995, p. 88. He quotes from the instructions to Serbian TV editors in 1990 whom the government asked to remove from their reports "nationalist symbols [which were] unacceptable to the majority of viewers ", such as Chetnik symbols and old Serbian flags (without a red star).

28. Ramet (Pedro), Yugoslavia in the 1980s', Boulder / London : Westview Press, 1985.

29. Tudjman (Franjo), Horrors of War [1989], New York : M. Evans and Company, Inc, 1996, p. 3.

30. Bogdanović (Bogdan), op. cit., p. 23.

31. Ramet (Pedro), op. cit.

\section{INDEX}

Index géographique : Yougoslavie

Mots-clés : Autogestion, Communisme, Ligue des communistes de Yougoslavie, Minorités, Socialisme

\section{AUTEUR}

DEJAN JOVIĆ

University of Stirling, UK 